\title{
Intramucosal Carcinoma of the Mouse Intestinal Tract
}

National Cancer Institute

\section{Source}

National Cancer Institute. Intramucosal Carcinoma of the Mouse Intestinal Tract. NCI

Thesaurus. Code C107672.

Infiltration of malignant glandular epithelial cells into the lamina propria of the intestine of the mouse without involvement of the submucosa. 